\begin{abstract}
Iranica
Abstracta Iranica Revue bibliographique pour le domaine irano-aryen

Volume 37-38-39 | 2018

Comptes rendus des publications de 2014-2016
\end{abstract}

\title{
Maria Macuch. « Ardashir’s Genealogy Revisited »
}

\section{Alessia Zubani}

\section{(2) OpenEdition}

\section{Journals}

Édition électronique

URL : http://journals.openedition.org/abstractairanica/45799

DOI : 10.4000/abstractairanica.45799

ISBN : 1961-960X

ISSN : 1961-960X

Éditeur :

CNRS (UMR 7528 Mondes iraniens et indiens), Éditions de l'IFRI

Référence électronique

Alessia Zubani, « Maria Macuch. "Ardashir's Genealogy Revisited » », Abstracta Iranica [En ligne],

Volume 37-38-39 | 2018, document 24, mis en ligne le 30 décembre 2018, consulté le 28 septembre

2020. URL : http://journals.openedition.org/abstractairanica/45799; DOI : https://doi.org/10.4000/ abstractairanica.45799

Ce document a été généré automatiquement le 28 septembre 2020.

Tous droits réservés 


\title{
Maria Macuch. « Ardashir's Genealogy Revisited »
}

\author{
Alessia Zubani
}

\section{RÉFÉRENCE}

Maria Macuch. « Ardashir’s Genealogy Revisited », Iran Nameh, vol. 29 (2), 2014, p. 80-94

1 La généalogie royale et mythique d'Ardašīr est un point fondamental de la propagande légitimatrice de la maison sassanide. L'A. présente de nouvelles considérations à cet égard, à la lumière des récits sur la naissance d'Ardašīr figurant dans les sources primaires (inscription de Šābuhr I à Naqš-i Rustam, textes moyen-perses, Histoires d'Agathias et littératures en arabe et persan) grâce aux outils offerts par le droit familial sassanide. Les sources présentent en effet des versions différentes de cette généalogie, où la présence des personnages tels qu'Ardašīr, Pābag et Sāsān, combinée à la référence au mariage endogamique et au thème de l'adoption, représentent la seule constante. En analysant les types de mariage prévus par la loi sassanide on peut comprendre la nécessité de lier génétiquement la personne du fondateur soit à Pābag soit à Sāsān, à travers la médiation de la mère (fille ou femme de Pābag ou fille de Sāsān). La seule exception se trouve dans les récits plus tardifs des littératures arabes et persanes, où prévaut un système généalogique patrilinéaire. 


\section{AUTEURS}

\section{ALESSIA ZUBANI}

Doctorante EPHE, Mondes iranien et indien, Paris 